\title{
Complexity of L2 Motivation in an Asian ESL Setting
}

\author{
Muhammad Shahbaz and Yongbing LiU \\ Northeast Normal University
}

Received: 12 January 2012 / Accepted: 14 March 2012

ISSN: 1697-7467

\begin{abstract}
Drawing upon the data from 547 ESL learners in Pakistan, this study presents a complex picture of L2 learning motivation by means of descriptive as well as inferential analyses. The results show that no single factor predicts L2 learning motivation for the target population. Language learning experience, international orientation, ideal L2 self and instrumentality all work interconnected to motivate ESL learners. English as an international language has a strong influence on ESL learning for Pakistani learners with their colonial past. This study suggests that teachers have to focus on attitudinal, situational and self-related factors to keep their students motivated for a long time process of L2 learning.
\end{abstract}

Keyword: L2 learning motivation, Dynamic process, Pakistan, EIL

\section{Complejidad de la Motivación en la segunda lengua en el contexto asiático del inglés como segunda lengua}

RESUMEN: Basándose en los datos de 547 estudiantes de ESL en Pakistán, este estudio presenta un panorama complejo de la motivación en el aprendizaje de una L2, llevado a cabo mediante análisis descriptivos e inferenciales. Los resultados muestran que no hay un solo factor que pueda predecir la motivación en el aprendizaje de un L2. La motivación de los alumnos para estudiar inglés como una L2 se debe al trabajo interconectado de una adecuada experiencia de una orientación internacional y un L2 ideal. En particular el idioma Inglés, como lengua internacional, tiene una gran influencia en los estudiantes Pakistaníes con un pasado colonial. El presente estudio sugiere que los profesores tienen que centrarse en la actitud y la situación para mantener a sus estudiantes motivados durante el largo tiempo que requiere el aprendizaje de una L2.

Palabras clave: La motivación de un L1, Proceso dinámico, Pakistán, EIL

\section{INTRODUCTION}

A great deal of research on second language learning motivation (SLLM) in last 3 decades has underlined motivation as an important individual learner variable in second language acquisition (SLA) (e.g., Gardner, 1985, 2001, 2010; Dörnyei, 2003, 2005; Dörnyei \& Ushioda, 2011; Noels, 2003, 2005; Ushioda, 2007, 2009). L2 learners' behaviour and thinking are associated with motivation and motivated individuals act in a goal-directed and purposeful manner. Motivation is termed as the most influential factor in L2 learning 
by Gardner (1985). L2 motivation is primary driving force for long-term process of learning an L2 and 'all the other variables involved in SLA presuppose motivation to some extent' (Dörnyei, 2005:65). Cohen and Dörnyei (2002:172) claim, «Motivation is often seen as the key learner variable because without it, nothing much happens.»

Lambert and Gardner (1959), two social psychologists, first studied motivation in L2 learning. Gardner's Socio-educational (SE) model (1985) has been topic of debate and research in L2 learning field for many years. Gardner introduced his famous AMTB (Attitude/Motivation Test Battery), a psychometric tool to measure the effects of attitude and motivation in L2 learning contexts. Gardner (2001) explains that SLLM consists of three elements, motivational intensity or effort (effort expended to learn a language), desire to learn the language (wish to achieve the desired L2), attitudes towards learning the language (enjoyment of the task).

Gardner revised and modified his work in two decades (Tremblay \& Gardner, 1995; Gardner et al., 2001 and Masgoret \& Gardner, 2003) to face challenges and criticism from other scholars in the field. Many scholars (Dörnyei, 1994a; Oxford, 1994) have criticized the over emphasis on integrative motivation. Much of the criticism relates to the term integrativeness, as there is no parallel of term in mainstream psychology (Dörnyei, 2001). The understanding of this term is also different, at times even contradictory, among scholars. The growing importance of English as an international language has a strong influence over L2 learning in EFL contexts and researchers (Dörnyei, 2001; Lamb, 2004; Chen et al., 2005) show that the role of integrative orientation is fairly low from what has been suggested by Gardner. The concept of identification with L2 has also been criticized by many (Pennycook, 1995; Webb, 2002). However, despite this severe criticism, the fact remains that Gardner's pioneering work in the field has provided us new insights and directions and his contribution to this field is noteworthy. Dörnyei (1994b:519) states, «Having been familiar with the Gardnerian approach for a long time, we may not always be conscious of how much of a 'breakthrough' this was».

The 1990 has witnessed great deal of dissatisfaction with L2 motivational theories. Concepts from different approaches were included to deal with complex, dynamic nature of motivation. Dörnyei's (1994a) framework was the first to respond to a demand in the change of directions in SLLM. He conceptualized motivation at three levels:

1- Language Level

2- Learner Level

3- Learning Situation Level

The language level covers different aspects of L2 like culture, community, pragmatic, and utilitarian benefits attached with it. The learner level entails distinctive features of the individual that he/she brings to the learning process. The learning situation considers to specific motives in the language learning classroom setting like course, teacher and group specific components.

Another important theory in the area of SLLM is Self Determination theory (SDT). SDT «is one of the most influential theories in the motivational psychology» (Dörnyei, 2003). SDT in L2 context owes much to the work of Noels and her colleagues (Noels, 2001, 2003, 2009; Noels et al., 2000, 2001). A major contribution of the theory is focusing on 
creating conditions where people can motivate themselves. Noels (2001) differentiates concept of intrinsic and extrinsic motivation at various levels in educational settings. In her opinion, intrinsic motivation has three subcomponents namely:

1- Knowledge (pleasure to learn new things in life or in L2),

2- Accomplishment (satisfaction to successfully complete goals or tasks),

3- Stimulation (arousal of pleasure in doing the activity itself)

Ushioda (2009) has proposed a 'person-in-context relational view of motivation' that emphasizes the importance of real individual dealing with everyday realities of life. This view is in sharp contrast to the traditional concept of SLLM where 'ideal or imagined' language learner is focus of attention. Her framework deals with the complexity of motivation, self and context with special reference to the 'organic whole' of the individual. She stresses that learning an L2 is just one part of the identity that individuals have living in a society and we need to bring together all others aspects (like second language learner, student, son, brother, friend, player, and many other facets) to develop a true understanding of SLLM.

The problem, according to Dörnyei (1996), is not lack of theories rather an abundance of theoretical frameworks. In past decades, many SLLM theories have mushroomed (see Dörnyei, 2005 for review). However, most of the existing models focus on motivation as a linear system where dynamic nature of motivation is often ignored. Similarities rather than differences among these multiple frameworks create complex situation and pose hurdles to develop fuller understanding of SLLM. There are some scholars focusing on dynamic nature of motivation like Ushioda (2009), however, a unique approach among one of the recent developments is Dörnyei's L2 Motivational Self System. Dörnyei and his colleagues (Dörnyei, Csizér, \& Németh, 2006; Csizér \& Dörnyei, 2005; Dörnyei \& Csizér, 2002; Dörnyei \& Clément, 2001), with the help of large-scale study in Hungry, have argued for reinterpretation of the concept of integrativeness in SLLM research. They argue:

We suspect that the motivation dimension captured by the term is not so much related to any actual, or metaphorical, integration into an L2 community as to some more basic identification process within the individual's self-concept. As described above, such a conception would not conflict with the original Gardnerian notion and would at the same time provide a broader frame of reference. (Dörnyei \& Csizér, 2002:453)

Based on their empirical findings and drawing on the theories of 'possible selves' (Higgins, 1987) in mainstream psychology, Dörnyei $(2005,2009$ a) has proposed an L2 Motivational Self System (LMSS). He suggests that concept of ideal L2 self would be better able to explain complex and dynamic nature of L2 learning. The concept of integrativeness has not been able to explain the learning situation in many contexts. The identification with L2 community (as Gardner suggests) in today's globalised world, especially in case of global English as an L2, does not seem to fully encompass the SLLM. LMSS has three components at its base: 
Ideal L2 Self, which is L2 specific facet of one's 'ideal self'. It links with goals and desires of the language learner.

Ought-to L2 self, which concerns the attributes that one believes one ought to possess to meet expectations and to avoid possible negative outcomes (like obligations and responsibilities as a language learner).

L2 Learning Experience, which concerns situated, executive motives related to immediate learning environment and experiences (success or failure).

(Dörnyei, 2009:29)

The underlying hypothesis is that if proficiency in L2 is deeply rooted in one's ideal or ought-to self, this will be a powerful motivating factor to learn the target language. This accounts for our psychological desire to fill in or decrease the gap between current and future possible selves. Lamb (2004) argues that SLLM for Indonesian students is the result of 'bicultural identity', local as well as global citizens. The assumption is that learners will invest a great deal of time and effort in L2 if this helps them to maintain or in case develop their own identity.

Thus, we can assume that this newly emerging system will work well in SLLM context. This hypothesis makes the basis of current study. The authors believe that those learners who have a clear image of the self and a positive learning experience will be better able to develop abilities in second or foreign language, which in case of Pakistan happens to be English. Based on recent literature (Ryan, 2009; Taguchi et. al., 2009), figure 1 is a hypothetical representation for our study:

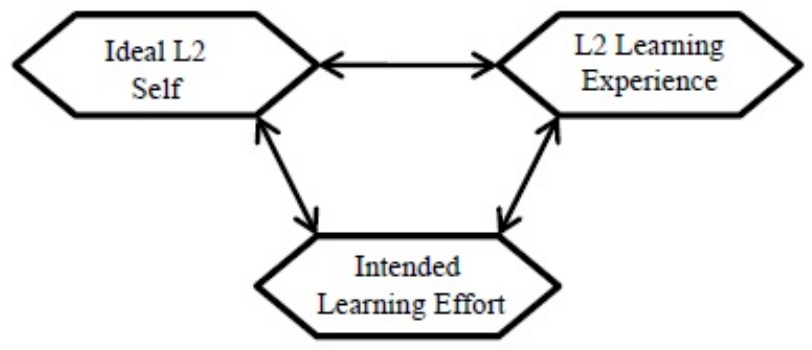

Figure 1. Hypothetical Model of Motivational Factors Influencing L2 Effort

\section{Purpose of the study}

Research on SLLM in Pakistan has been lagging behind largely. There is not enough research on motivation in mainstream or even educational psychology. In SLLM, there are no representative studies to explain reasons for Pakistani students to learn English. Research on SLLM is shockingly underdeveloped. There is single $\mathrm{PhD}$ thesis by Ghani (2002) from Essex University where motivation to learn English becomes part of research along with language learning strategies and other factors. Another exception is a recently published article about the motivation of 47 senior secondary school students by Malik (2010). There are no other studies conducted or published works on SLLM research to the best knowledge of the authors. 
Given the importance of motivation in everyday life and the prior research on SLLM in the world, these two studies serve no better purpose for developing real understanding of SLLM in Pakistan. Therefore, the current study measures some of the factors that motivate 1st year (grade 11) college students in Pakistan to learn English. Specifically, it is to answer the following research questions:

1- Do instrumentality, integrativeness and ideal L2 self affect the SLLM for first year college students in Pakistan?

2- Are there any other factors, besides those mentioned in quetion1, that strongly influence SLLM for ESL learners in Pakistan?

3- Does international English affect the motivation to learn English for this group of learners?

\section{DATA AND METhOD}

Keeping with psychometric tradition of SLLM research, this study has adopted quantitative research methodology. Different kinds of questionnaires help to ask the opinion of people about certain issues. And, as Dörnyei (2010:6) suggests that questionnaires are highly efficient in terms of a) researcher time, b) researcher effort and c) financial resources. Therefore, for the purpose of this study, we developed Motivational Elements Questionnaire (MEQ) with six point Likert scale by selecting items from previously established frameworks in SLLM research. Six point Likert scale focuses to avoid noncommitted answers from students by simply choosing neutral case (Ryan, 2008).

Initially, we selected 120 items pool with 12 broad categories with the help of literature review. Later, some items were deleted based on suggestions of practicing ESL teachers in Pakistan. At this initial stage, we deleted the category related to evaluation of classroom teachers. All three teachers suggested that it is better to delete this category, as many teachers would not simply cooperate just because of questions that seem to measure their role and proficiency.

As Dörnyei and Ushioda (2011) point out, no single model or framework can fully elaborate the intricate and vibrant process of motivation. Therefore, final questionnaire for pilot study contained items from different models. We adopted some items from Gardner's (1985) Socioeducational model. Cultural interest, instrumentality, attitude towards L2 community and attitude towards L2 learning are central to Gardner's model as well as Dörnyei \& Csizér (2002) and these are included to see their effect in Pakistani context. Items to assess English anxiety (both within and out of classroom) were adopted from Dörnyei and Csizér (2002).

Yashima's (2002) concept of international posture developed in Japan is much important in Pakistani context as many young people learn English to communicate with friends and family members living abroad. More than 7 million (Eteraz, 2009) Pakistanis work, study or live abroad. Items for Ideal L2 self and intended learning effort have been adopted from Ryan (2009). Items for ideal L2 self measure the role played by imagined personal image created by learners. Items for intended learning effort try to encompass current as well as future efforts of learners. 
For the pilot study, an English teacher delivered a questionnaire containing 104 items to 50 students from target group. All of them filled the questionnaire within their class time. Pilot study helped to improve questionnaire. Based on results, some items with no significant differences were deleted for time saving purposes. We reorganized some items while in others easy to understand words replaced difficult words. For example, item 2 was omitted as item 1 can work well for its place, item 3 was reorganized as item 4, item 5 was rewritten as item 6 , item 7 was rephrased as item 8 .

1. Is it important to learn English if you want to know more about culture and art of its speakers?

2. Learning English well can help me appreciate literature and artistic works of English-speaking people.

3. For me to become an educated person I should learn English.

4. I should learn English to become educated.

5. I think I am the type who would feel anxious and ill at ease if I had to speak to someone in a foreign language.

6. I think I will feel uncomfortable while speaking a foreign language.

7. English ability would help me get a better paying job.

8. English would help me get a better paying job.

\subsection{Participants}

Participants of this study were 547 first year college students from three districts of Punjab province in Pakistan. Districts were selected with random sampling while four colleges ( 2 boys, 2 girls: 2 public, 2 private) from each district were selected based on cluster sampling. Further 50 students from each college were chosen using stratified random sampling technique.

As table 1 illustrates, sample comprised of almost equal number of boys (263) and girls (259) while age of the participants range from 15 to 18 years. Information regarding gender was missing from 25 questionnaires.

Table 1. Gender and Age of Participants

\begin{tabular}{|l|c|c|c|c|c|}
\hline \multirow{2}{*}{ TOTAL } & \multicolumn{3}{|c|}{ GENDER } & \multicolumn{2}{c|}{ AGE } \\
\cline { 2 - 6 } & Boys & Girls & Missing & Mean & SD \\
\hline 547 & $263(48.1 \%)$ & $259(47.3 \%)$ & $25(4.6 \%)$ & 16.85 & 1.06 \\
\hline
\end{tabular}

\subsection{Data collection Procedure}

Data were collected in September/October 2010. To make it user friendly, final version of the questionnaire took shape of a nice, presentable booklet of two double-sided pages. First part contained the questions regarding MEQ while there were some biographical questions at the last page making the second part of the questionnaire.

The first author (along-with respective teachers) visited all classrooms personally to collect the data. Students were first told about the purposes of research and they were 
allowed to ask questions if any. They were assured of confidentiality and issue of anonymity. Then, the researcher read aloud all instructions in beginning of questionnaire and special instructions made clear to complete the measures for six point Likert scale. After clear understanding, students completed questionnaires while the researcher remained in classroom to answer questions. This procedure took almost 25 to 30 minutes for all students in each class to finish and we thanked students for their participation.

\subsection{Data Analysis}

After data collection, the first author inserted all data into SPSS 17 data sheet. In this process, 53 questionnaires were discarded where there was not enough information provided by the respondents or a set pattern used to choose answers. Later, an M.A. student helped to check for mistakes if any. Using SPSS 17 assisted to measure the internal reliability of items for different scales to find if they work well to determine the supposed categories. Some of the items were excluded to improve the reliability of results. Further, descriptive statistical analysis (mean, SD) as well as inferential statistics (Correlation analysis) was computed to answer the questions posed for this study.

\section{Results AND Discussion}

Internal consistency of scales was measured using SPSS 17 and overall consistency remains good. Cronbach's alpha over 0.60 is normally suitable for large-scale studies (Dörnyei and Taugchi, 2010). Table 2 demonstrates reliability analysis for the items.

Table 2. Internal Reliability of Scales used in $M E Q$

\begin{tabular}{|l|l|}
\hline \multicolumn{1}{|c|}{ Scale } & alpha \\
\hline Attitude towards learning English (06) & 0.80 \\
\hline Attitude towards L2 Community (08) & 0.72 \\
\hline Cultural Interest (05) & 0.61 \\
\hline Instrumentality (10) & 0.85 \\
\hline Ideal L2 Self (06) & 0.75 \\
\hline Intended Learning Effort (08) & 0.79 \\
\hline English Anxiety (06) & 0.67 \\
\hline Milieu (08) & 0.67 \\
\hline L2 Self confidence (04) & 0.53 \\
\hline Interest in Foreign Languages (05) & 0.65 \\
\hline International Orientation (09) & 0.81 \\
\hline
\end{tabular}

Most of the scales show good internal consistency, however, some of the items do demonstrate low alpha. We can explain this low alpha with help of alpha (0.47) in the original Hungarian studies where Dörnyei and his colleagues used L2 self-confidence (Dörnyei et al., 2006). Again comparatively low number of items in this scale can account for this phenomenon. 


\subsection{Descriptive Analysis}

As table 3 illustrates, descriptive analysis tells us that scale with the highest mean score (4.83) and lowest standard deviation (SD) (1.52) is instrumentality. In modern competitive world, many students learn English in Pakistan for purely instrumental reasons (Malik, 2010). English is a gateway to success and prestige in Pakistan (Rahman, 2005; Ghani, 2003). Going abroad and meeting international people can be a part of instrumental motivation as the purpose to visit foreign countries is normally to develop business or better understanding of international economic scenario. High average score of international orientation (4.58) might result from learners' yearning for an international or global identity with the help of English as a lingua franca (Jenkins, 2006).

The third ranked item is ideal L2 self which is also comparatively high scoring (4.55). This is particularly high compared to attitudes towards L2 community (3.84) and cultural interest (3.28), the two central focal points for integrative construct of Gardner's socioeducational model. This fact explains the importance of ideal L2 self-images in motivating students to learn English in modern globalized world. Attitude towards learning English (4.51) is the fourth highly ranked in the table 3 . This once again points to the importance of English as an international language where English is helping learners to develop their global and local identities at the same time. A positive attitude towards English as a language, and not as a property of target culture or community, might work well to motivate students to learn English, particularly at this early stage in their college life.

Table 3. Descriptive analysis of scales used for MEQ

\begin{tabular}{|l|c|c|}
\hline \multicolumn{1}{|c|}{ Scale } & Mean & SD \\
\hline Instrumentality & 4.83 & 1.52 \\
\hline International Orientation & 4.58 & 1.56 \\
\hline Ideal L2 Self & 4.55 & 1.58 \\
\hline Attitude towards Learning English & 4.51 & 1.61 \\
\hline Interest in Foreign Languages & 4.41 & 1.57 \\
\hline Intended Learning Effort & 4.36 & 1.63 \\
\hline Milieu & 4.22 & 1.59 \\
\hline Attitude towards L2 Community & 3.84 & 1.76 \\
\hline L2 Self Confidence & 3.66 & 1.74 \\
\hline English Anxiety & 3.28 & 1.70 \\
\hline Cultural Interest & 3.28 & 1.80 \\
\hline
\end{tabular}

Attitude towards L2 community (3.84) is a low scoring scale. There are different factors involved in this attitude. Post 9/11 scenario in the world has really influenced the view of English speaking countries, especially so for USA. Issues like Afghanistan, Iraq and even war in some areas of Pakistan and role of NATO and USA forces might have radically changed the attitude of youth towards these countries. The lowest scoring scale of cultural interest (3.28) tells us about low interest from Pakistani youth for English speaking cultures. Low scores for attitude towards L2 community and cultural interest are also in line with observations made by Malik (2010) for intermediate students in Pakistan. 
Although modernization is taking routes in many parts, Pakistani youth with strong influence from religion might have some apprehensions for culture of English speaking countries. These results are also in accordance with previous literature (Ryan, 2008; Taguchi et al., 2009). The difference between individualistic societies of the West and collectivist culture of Pakistan is possibly another reason and students might find it in a clash with their local culture and identities. In this vein, Norton (2000) argues that learners will invest in target language to negotiate for a broad range of symbolic as well as material resources that will help them to develop their cultural capital, enhance their identity and positive attitude towards future. Simple identification with target community is not a clear view reflecting multilingual people with multiple identities in the modern world (Pavlenko, 2002). Taking world Englishes perspective, Coetzee-Van Rooy (2006) asserts that, in postcolonial World English contexts, the concept of integration with target community is 'untenable'. This is very much evident in our data with two scales for integrativeness scoring low for these learners in a postcolonial setting of Pakistan.

\subsection{Co-relational Analysis}

To answer the questions concerned with study, co-relational analyses were done using SPSS 17. With the help of co-relational analysis, we will be better able to understand the interactive relationship among different variables for motivating students to learn English in Pakistan. Co-relational analysis revealed very interesting as well as somewhat different results from previous studies. Table 4 portrays a clear picture of correlations of all scales with intended learning effort (criterion measure in this study).

Table 4. Correlation of all variables with Intended Learning Effort

\begin{tabular}{|l|c|}
\hline \multicolumn{1}{|c|}{ Scale } & Correlation \\
\hline Attitude towards learning English & $0.76^{* *}$ \\
\hline International Orientation & $0.74^{* *}$ \\
\hline Ideal L2 Self & $0.71^{* *}$ \\
\hline Instrumentality & $0.65^{* *}$ \\
\hline Attitude towards L2 Community & $0.50^{* *}$ \\
\hline Milieu & $0.50^{* *}$ \\
\hline Interest in Foreign Languages & $0.50^{* *}$ \\
\hline Cultural Interest & $0.47^{* *}$ \\
\hline L2 Self confidence & $0.24^{* *}$ \\
\hline English Anxiety & $-0.31^{* *}$ \\
\hline
\end{tabular}

**Correlation is significant at $\mathrm{p}<0.01$ level.

A strong correlation of intended learning effort with all variables creates a complex situation. Table 4 makes it clear that four variables have high correlations with criterion measure of intended learning effort. Although positioning of top four factors is little bit changed, four high scoring scales in descriptive analysis also depict a strong relation with current or possible efforts used by students to learn English. Attitude towards 
learning English $(\mathrm{r}=.76)$, international orientation $(\mathrm{r}=.74)$, ideal L2 self $(\mathrm{r}=.71)$, and instrumentality $(\mathrm{r}=.65)$ all indicate strong influence of these factors in L2 learning motivation. No single variable seems to outperform others. This is in line with the existing beliefs that motivation is complex and dynamic phenomenon (Dörnyei, 2009b, Dörnyei \& Otto, 1998). Recent focus on dynamic systems theory and its implications for SLA and applied linguistics (Larsen-Freeman \& Cameron, 2008; van Geert, 2008; Ellis \& Larsen-Freeman, 2006) also signal the same complex nature of L2 acquisition process.

The results of co-relational analysis presented in Table 4 highlight some important factors involved in ESL learning in Pakistan. For this group of learners, there is significantly high correlation between intended learning effort and attitude towards learning English which suggests that there is strong and direct relationship between these two (Ryan, 2008). We can say that learners will put more efforts if they enjoy the learning process itself. The process of learning should be enjoyable and students should feel comfortable about different aspects of learning English.

International posture as presented by Yashima (2002) has emerged a strong factor in our research data. Internationalization has become the order of the day and no one can deny its strong impact on world masses. In recent years, Pakistan has made major advances in information and technology and access to internet, and to English, has increased rapidly. Thus, Pakistani students feel part of international community and they want to add to as well as receive from the ongoing process of globalisation. Communication with international friends and family members living abroad (more than 7 million Pakistanis live abroad) and the attraction of international resources for jobs and higher education fills them with energy to put efforts for ESL learning. The role of English as an international language and its importance in global scenario works as igniting force for motivation to learn English. These results for international orientation are different from previous studies (Ryan, 2009; Dornyei et al., 2006) and point to the uniqueness of Pakistani cultural context and colonial past.

Table 4 demonstrates that ideal L2 self also has strong correlation with intended learning effort and this is in line with previous work on SLLM and ideal L2 self (Ryan, 2009; Taguchi et al., 2009; Csizér \& Kormos, 2009). Learners with a clear vision of their future are supposed to put enough effort to learn the target language. If learners want to be competent speakers or users of a target language, their future vision will help them to regulate their L2 learning, which in turn will enhance their motivation to learn target language, in this case English.

In this highly competitive world, many learners learn a language for instrumental reasons. Traditionally, it has been given little attention in SE model of SLLM. However, the role of short-term benefits of getting good grades, pleasing teachers or others is difficult to overlook in L2 learning and especially so with our studied population. There is high correlation $(\mathrm{r}=.65)$ between instrumental motivation and intended learning effort. Many students learn English to pass exams or to get admission into good universities. Many learners in Pakistan learn it as a school subject and focus on achieving grades. Many government jobs still focus on grades and score in a particular subject without giving due importance to communicative abilities. Malik (2010) also points to the same 
situation in conclusion of his paper. Even teachers believe that prestige in society is important reason for success in ESL. Although scholars (Deci \& Ryan, 2002; Noels, 2001) usually believe that extrinsic or instrumental motivation does not help learners to sustain motivation for long time, the complexity of motivation process is hard to ignore. Even for short time goals, instrumental motivation does affect learning. Longitudinal studied would be required to develop better understanding of this phenomenon.

English anxiety has significant negative correlation with intended learning effort (.31). This is in line with previous research where SLLM and anxiety are negatively correlated (Papi, 2010; Jackson, 2002; MacIntyre, 1995). Motivation to learn an L2 or efforts made by learners are usually in an inverse relationship with anxiety and many researchers (Sheen, 2008; Ohata, 2005) have suggested strategies to deal with the phenomenon of anxiety within L2 contexts. Variables like attitude towards L2 community, milieu, interest in foreign languages and cultural interest all depict a considerable correlation. However, high correlation of other factors and same level correlation of these four factors show that these factors are not strong predictors of ESL learning motivation for this group of learners and target population. We cannot deny their impact but focusing on highly correlated variables, we might be better able to explain SLLM.

\subsection{Inter-correlations and Partial Correlations}

Further co-relational analyses were performed to develop our understanding of SLLM for Pakistani learners of English at first year college level. Table 5 shows that all major variables not only have significant correlation with the criterion measure of intended learning effort but all of them also have very strong correlation (re».70) with each other. This fact points to the complexity of SLLM in the changing world. These four factors focus to measure quite different things but this strong correlation among them points to the dynamic and interactive nature of SLLM for these learners. Working from different perspectives, all these factors help learners to be largely motivated. The discussion in preceding paragraphs and table 5, help to make it clear that a simple and traightforward relationship between L2 motivation and learning is difficult to suggest. The notions of integrative and instrumental motivation, or even intrinsic and extrinsic motivation, would not be able to fully understand and explain the process of SLLM. LMSS might be in better position to explain the process, as all three concepts in it are dynamic and related to each other. International orientation and instrumentality can represent ought-to-selves for many in Pakistan. 
Table 5. Inter-correlations of Intended Learning Effort and four highly correlated variables

\begin{tabular}{|c|c|c|c|c|c|}
\hline & $\begin{array}{c}\text { Intended } \\
\text { Learning } \\
\text { Effort }\end{array}$ & $\begin{array}{c}\text { Attitude } \\
\text { towards } \\
\text { Learning } \\
\text { English }\end{array}$ & $\begin{array}{c}\text { International } \\
\text { Orientation }\end{array}$ & $\begin{array}{c}\text { Ideal L2 } \\
\text { Self }\end{array}$ & Instrumentality \\
\hline Intended Learning & 1 & & & & \\
\hline \multicolumn{6}{|l|}{ Effort } \\
\hline Attitude towards & $.76^{* *}$ & 1 & & & \\
\hline \multicolumn{6}{|l|}{ Learning English } \\
\hline International & $.74 * *$ & $.72 * *$ & 1 & & \\
\hline \multicolumn{6}{|l|}{ Orientation } \\
\hline Ideal L2 Self & $.71^{* *}$ & $.73 * *$ & $.76^{* *}$ & 1 & \\
\hline Instrumentality & $.65^{* *}$ & $.71 * *$ & $.74 * *$ & $.70^{* *}$ & 1 \\
\hline
\end{tabular}

**Correlation is significant at $\mathrm{p}<0.01$ level.

To develop our understanding of multifaceted relations among these factors, we computed partial correlation analyses. Figure 2 presents results for these correlations controlling for different variables.

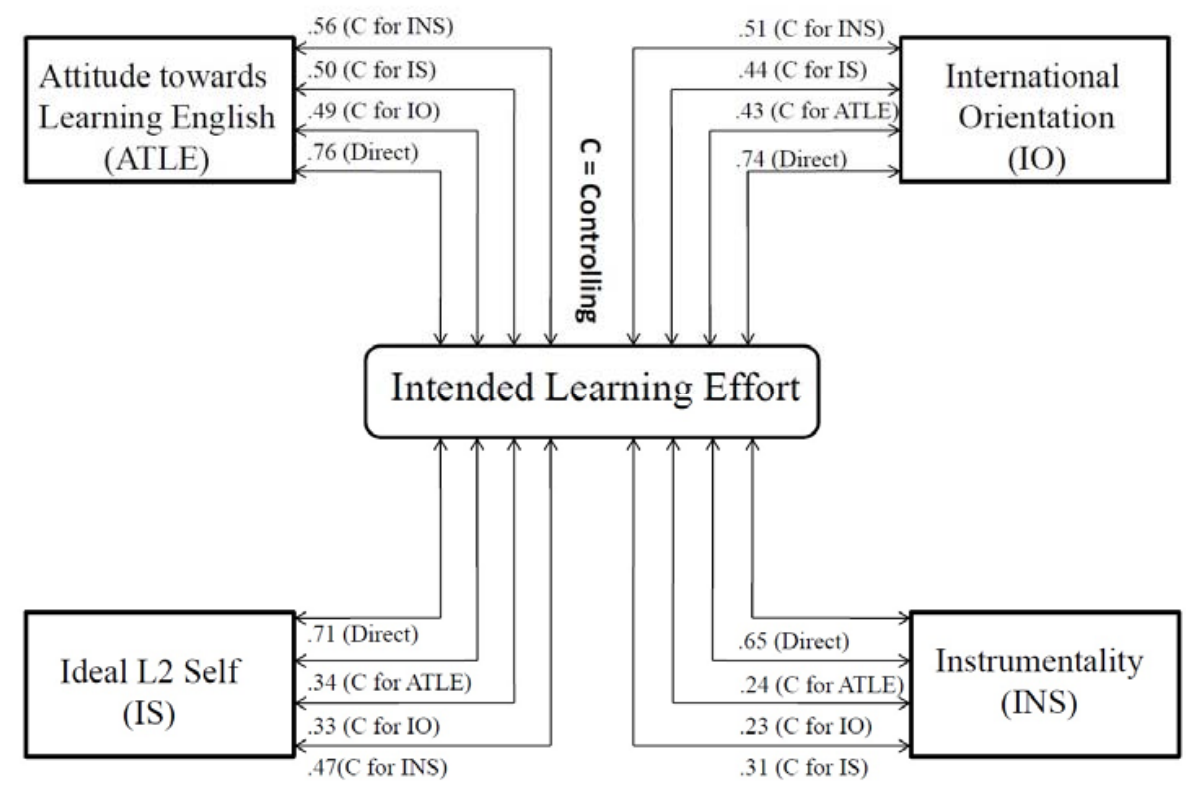

Correlations are significant at $\mathrm{p}<0.01$ level.

Figure 2. Partial-correlations of Intended Learning Effort with four highly correlated Variables 
Figure 2 explains the complexity of the process. All major factors have strong impact on other factors involved in motivational process. Average high partial correlations for attitude towards learning English ( $\mathrm{r}=.52)$, international orientation (.46), ideal L2 self (.38) and instrumentality (.26) points to dynamic nature of L2 learning process. It is easy to infer that social, psychological and contextual factors all influence L2 learning to a great degree. Controlling for attitude towards learning English affects all other variables strongly where international orientation, ideal L2 self and instrumentality fell from .74 to .43, from .71 to .34 and .65 to .24 respectively. This confirms its impact with previous literature. The effect of factors remains same with attitude towards learning English shaping the role of other factors significantly and other factors do not influence it greatly. Partial correlation analyses make us clear that different factors contribute to the enhancement of SLLM. Language is a 'complex adaptive system' (Five Graces Group, 2009) and this is especially so in the case of L2 learning. Partial correlation analyses have presented an intricate picture of SLLM with different factors working together to make learning process a 'living organism'.

The hypothesized factor of attitude towards L2 learning (figure 1) depicted strong relation with L2 motivation in descriptive as well as inferential analyses. This fact is in line with previous literature discussed in this paper. The second hypothesized factor of ideal L2 self to affect L2 motivation (figure 1), however, do not secure its second position in our studied population. International orientation figures out to be a strong element to motivate this group of ESL learners. Ideal L2 self is still a major factor as it has high score and strong correlation. This fact can account for cultural and contextual factors that are unique to Pakistani context.

\section{Conclusion}

To sum up, we have discussed the role of different important factors motivating ESL learners in Pakistan. Our data have presented a complex picture of the overall process of SLLM for this group of learners. We suggest that there is a need to understand SLLM from this complex perspective and focus on single notions like integrative or intrinsic motivation might not be able to explain the process. L2 learning experience is the most strongly affecting factor. Two of the three hypothesized motivational factors have worked well in this context. Integrative motivation does affect learning effort but it is hard to define in the strict Gardnerian definition.

Globalisation and spread of English as an international language have shaped SLLM a great deal for ESL learners. Now it is hard to negate the role of international English or English as a lingua franca while talking about teaching and learning of English. Teachers can enhance SLLM by making learning process enjoyable; by using materials from different parts of world and providing information about the world; by developing possible or future images for students- ideal or ought-to self images; and by focusing on short term as well long term material benefits of learning. Individualistic or contextual approaches (Ushioda, 2011; Kim, 2009) will be required to understand SLLM in this context. As the study is first of its kind in Pakistani context, further studies will be required to verify the results and plan strategies for motivating ESL learners in Pakistan. 
Further large scale, nationwide and longitudinal studies are required to develop better understanding of SLLM process.

\section{ACKNOWLEDGMENT}

First Author is thankful to China Scholarship Council and Ministry of Education Pakistan for an award of scholarship for Ph.D. studies. Comments from Michael Magid and Peng-Jian really helped to improve the quality of the paper. Credit goes to David Javier Santos Llave for abstract translation in Spanish. Special thanks go to all those students who participated in this project. Comments and suggestions from two anonymous referees were greatly helpful in improving the article. Of course, all mistakes remain ours.

\section{REFERENCES}

Coetzee-Van Rooy, S. (2006) Integrativeness: Untenable for world Englishes learners?, in World Englishes, 25(3-4): 437-50.

Chen, J.F., Warden, C.A. \& Chang, H.T. (2005). Motivators that do not motivate: The case of Chinese EFL learners and the influence of culture on motivation, in TESOL Quarterly, 39(4): 609-33.

Cohen, A.D. \& Dörnyei, Z. (2002). Focus on the language learning: Motivation, styles, and strategies, in N. Schmitt (ed.), An introduction to applied linguistics. London: Arnold, 170190.

Csizér, K. \& Dörnyei, Z. (2005). The internal structure of language learning motivation and its relationship with language choice and learning effort, in The Modern Language Journal, 89(1): 19-36.

Csizér, K., \& Kormos, J. (2009). Learning experiences, selves and motivated learning behaviour: A comparative analysis of structural models for Hungariansecondary and university learners of English, in Z. Dörnyei, and E. Ushioda (eds.). Motivation, Language Identity and the L2 Self. Bristol: Multilingual Matters, 98-119.

Deci, E.L. \& Ryan, R.M. (eds) (2002) Handbook of Self-Determination Research. Rochester, NY: The University of Rochester Press.

Dörnyei, Z. (1994a). Motivation and motivating in the foreign language classroom, in The Modern Language Journal, 78(3): 273-84.

Dörnyei, Z. (1994b). Understanding L2 motivation: On with the challenge!, in Modern Language Journal 78(4), 515-23.

Dörnyei, Z. (1996). Moving language learning motivation to a larger platform for theory and practice, in R. Oxford (ed.), Language learning motivation: The new century Honolulu: University of Hawaii, Second Language Teaching and Curriculum Center, 71-80.

Dörnyei, Z. (2003). Attitudes, orientations, and motivations in language learning: Advances in theory, research, and applications, in Z. Dörnyei (ed.), Attitudes, Orientations, and Motivations in Language Learning. Oxford: Blackwell, 3-32.

Dörnyei, Z. (2005). The Psychology of the Language Learner: Individual Differences in Second Language Acquisition. Mahwah, NJ: Lawrence Erlbaum.

Dörnyei, Z. (2009a). The L2 Motivational Self System, in Z. Dörnyei and E. Ushioda (eds), Motivation, Language Identity and the L2 Self. Bristol: Multilingual Matters: 9-42. 
Dörnyei, Z. (2009b). The Psychology of Second Language Acquisition. Oxford: Oxford University Press.

Dörnyei, Z. (2010). Questionnaires in Second Language Research: Construction, Administration, and Processing, 2nd edn. London: Routledge.

Dörnyei, Z. \& Ottó, I. (1998). Motivation in action: A process model of L2 motivation, in Working Papers in Applied Linguistics (Thames Valley University, London) 4: 43-69.

Dörnyei, Z. \& Clément, R. (2001). Motivational characteristics of learning different target languages: Results of a nationwide survey, in Z. Dörnyei \& R. W. Schmidt (eds.), Motivation and second language acquisition. Honolulu, Hawaii: Second Language Teaching and Curriculum Center, University of Hawaii at Manoa, 399-432.

Dörnyei, Z. \& Csizér, K. (2002). Some dynamics of language attitudes and motivation:Results of a longitudinal nationwide survey, in Applied Linguistics, 23(4): 421-62.

Dörnyei, Z., Csizér, K., \& Németh, N. (2006). Motivation, language attitudes, and globalisation: A Hungarian perspective. Clevedon, [England]: Multilingual Matters.

Dörnyei, Z. \& Ushioda, E. (2011). Teaching and Researching Motivation. Harlow, (England): Pearson Education Limited.

Ellis, N.C. \& Larsen-Freeman, D. (2006). Language emergence: Implications for applied linguistics - Introduction to the Special Issue, in Applied Linguistics, 27(4): 558-89.

Eteraz, A. (2009). Pride and the Pakistani Diaspora, in Daily Dawn, February, 14. Retrieved on 10/10/2010 from http://archives.dawn.com/archives/142435

Gardner, R. C. (1985). Social psychology and second language learning: The role of attitudes and motivation. London: Edward Arnold.

Gardner, R. C. (2001). Integrative motivation: Past, present and future. Distinguished Lecturer Serious. Temple University Japan, Tokyo, February 17, 2001.

Gardner, R.C. (2010). Motivation and Second Language Acquisition: The Socio-Educational Model. Bern: Peter Lang Publishers.

Gardner, R. C., \& Lambert, W. E. (1959). Motivational variables in second language acquisition, in Canadian Journal of Psychology, 13: 266-272.

Gardner, R. C., Masgoret, A.M., \& Bernaus, M. (2001). Examining the role of attitudes and motivation outside of the formal classroom: A test of the mini-AMTB for children, in Z. Dörnyei \& R. Schmidt (eds.), Motivation and second language acquisition. Honolulu, HI: Second Language Teaching \& Curriculum Center University of Hawaii at Manoa.

Ghani, M. (2002). The effects of social, attitudinal and motivational factors on English language proficiency: A study of Pakistani students at post-intermediate level. Unpublished $\mathrm{PhD}$ thesis, Essex University, UK.

Ghani, M. (2003). The Status and Position of English Language in Pakistan, in Journal of Social Sciences and Humanities, 1(1): 103-115.

Jackson, J. (2002). Reticence in second language case discussions: Anxiety and aspirations, in System, 30(1): 65-84.

Jenkins, J. (2006). Current perspectives on teaching world Englishes and English as a lingua franca, in TESOL Quarterly, 40(1): 157-81.

Kim, Tae-Young. (2009). The dynamics of L2 self and L2 learning motivation: A qualitative case study of Korean ESL students, in English Teaching, 64(3): 49-70.

Lamb, M. (2004). Integrative motivation in a globalizing world, in System, 32(1): 3-19.

Larsen-Freeman, D. \& Cameron, L. (2008). Complex Systems and Applied Linguistics. Oxford: Oxford University Press.

MacIntyre, P. D. (1995). How does anxiety affect second language Learning? A reply to Sparks and Ganschow, in The Modern Language Journal, 79(1): 90-99. 
Malik, G.T. (2010). Role of L2 Motivation and the Performance of Intermediate Students in The English (L2) Exams in Pakistan, in Language in India, 10(7): 37-49.

Masgoret, A. M., and Gardner, R. C. (2003). Attitudes, motivations, and second language learning: A meta-analysis of studies conducted by Gardner and associates, in Language Learning, 53(1): 123-163.

Noels, K.A. (2001). Learning Spanish as a second language: Learners' orientations and perceptions of their teachers' communicative style, in Language Learning, 51: 107-44.

Noels, K.A. (2003). Learning Spanish as a second language: Learners' orientations and perceptions of their teachers' communication style, in Z. Dörnyei (ed.). Attitudes, Orientations, and Motivations in Language Learning. Oxford: Blackwell, 97-136.

Noels, K. A. (2005). Orientations to Learning German: Heritage Language Learning and Motivational Substrates, in The Canadian Modern Language Review, 62(2): 285-312.

Noels, K.A. (2009). The internalisation of language learning into the self and social identity, in Z. Dörnyei, and E. Ushioda (eds), Motivation, Language Identity and the L2 Self. Bristol: Multilingual Matters.

Noels, K.A., Pelletier, L.G., Clément, R. and Vallerand, R.J. (2000). Why are you learning a second language? Motivational orientations and self-determination theory, in Language Learning 50(1): 57-85

Noels, K.A., Clément, R., and Pelletier, L.G. (2001). Intrinsic, extrinsic, and integrative orientations of French Canadian learners of English, in Canadian Modern Language Review 57(3): 42444.

Norton, B. (2000) Identity and Language Learning: Gender, Ethnicity and Educational Change. Harlow: Longman.

Ohata, K. (2005). Language Anxiety from the Teacher's Perspective: Interviews with Seven Experienced ESL/EFL Teachers, in Journal of Language and Learning, 3(1): 133-155.

Oxford, R.L. (1994). Where are we regarding language learning motivation?, in Modern Language Journal, 78(4): 512-14.

Papi, M. (2010). The L2 motivational self system, L2 anxiety, and motivated behavior: A structural equation modeling approach, in System, 38(3): 467-479.

Pavlenko, A. (2002) Poststructuralist approaches to the study of social factors in second language learning and use, in V. Cook (ed.), Portraits of the L2 User. Clevedon: Multilingual Matters, 277-302.

Pennycook. A (1995). English in the world / The world in English, in J.W. Tollefson (ed.), Power and inequality in language education. Cambridge: Cambridge University Press, 34-58.

Rahman, T. (2005) Passport to Privilege: The English Medium Schools in Pakistan, in Peace and Democracy in South Asia, Volume 1, Number 1, January 2005.

Ryan, S. (2008). The Ideal L2 Selves of Japanese Learners of English. Unpublished PhD Thesis, Nottingham University, UK.

Ryan, S. (2009). Self and Identity in L2 Motivation in Japan: The Ideal L2 Self and Japanese Learners of English, in Z. Dörnyei and E. Ushioda (eds.) Motivation Language Identity and L2 Self. Bristol: Multilingual Matters, 120-143.

Sheen, Y. (2008). Recasts, Language Anxiety, Modified Output, and L2 Learning, in Language Learning, 58(4): 835-874.

Taguchi, T., Magid, M., \& Papi, M. (2009). The L2 Motivational Self System among Japanese, Chinese and Iranian learners of English: A comparative study, in Z. Dörnyei and E. Ushioda (eds). Motivation, Language Identity and the L2 Self. Bristol: Multilingual Matters, 66-97. 
The «Five Graces Group», Beckner, C., Blythe, R., Bybee, J., Christiansen, M. H., Croft, W., Ellis, N. C., Holland, J., Ke, J., Larsen-Freeman, D. \& Schoenemann, T. (2009). Language Is a Complex Adaptive System: Position Paper, in Language Learning, 59(1): 1-26.

Tremblay, P. F. \& Gardner, R. C. (1995). Expanding the motivation construct in language learning, in Modern Language Journal, 79: 505-518.

Ushioda, E. (2007) Motivation and language, in Östmann, J-O. and J. Verschueren, (eds), Handbook of Pragmatics. Amsterdam: John Benjamins.

Ushioda, E. (2009) A person-in-context relational view of emergent motivation, self and identity, in Z. Dörnyei and E. Ushioda (eds) Motivation, Language Identity and the L2 Self. Bristol: Multilingual Matters, 215-228.

Ushioda, E. (2011). Why autonomy? Insights from motivation theory and research, in Innovation in Language Learning and Teaching, 5(2): 221-232.

Van Geert, P. (2008). The dynamic systems approach in the study of L1 and L2 acquisition: An introduction, in The Modern Language Journal, 92(2): 179-199.

Webb, V. (2002). English as a second language in South Africa's tertiary institutions, in World Englishes, 21(1): 63-81.

Yashima, T. (2002). Willingness to communicate in a second language: The Japanese EFL context, in The Modern Language Journal, 86(1): 54-66. 